Journal Universitas Muhammadiyah Gresik Engineering, Social Science, and Health International Conference (UMGESHIC)

UMGCINMATIC : $1^{\text {st }}$ Rethinking Education during Covid-19 Era: Challange and Innovation

\title{
KH IMAM ZARKASYI'S LIFE PRINCIPLES IN EDUCATION OF MODERN PONDOK SANTRI DARUSSALAM GONTOR IN MUHAMMAD RIDLO ZARKASYI'S BOOK
}

\author{
Ulil Abshar Ubaidillah ${ }^{1}$, Hasan Basri ${ }^{2}$, Moh Ahyan Yusuf Sya'bani ${ }^{3}$ \\ ${ }^{1}$ Student of Islamic Religious Departement, Universitas Muhammadiyah Gresik \\ ${ }^{2}$ Lecturer of Islamic Religious Departement, Universitas Muhammadiyah Gresik \\ ${ }^{3}$ Lecturer of Islamic Religious Departement, Universitas Muhammadiyah
}

Gresik Email: ubaidillahulil@gmail.com, hasanbasri.mdr@gmail.com ,

ahyanyusuf@umg.ac.id

\begin{abstract}
KH Imam Zarkasyi is an ideal educator who has been successful in the development of education and teaching, especially in fostering the quality of his students. A century has passed since Pondok Modern Darussalam Gontor has continued to take part in the community. Pondok Modern Darussalam Gontor has produced alumni who already have names in the public. The motivation for success in today's society aims to remind people of success ambitions that were once forgotten for a moment. The secret of success as outlined in this article is expected to be able to stimulate thoughts and behavior to keep the spirit of fighting in the mirror from the secret of success according to KH Imam Zarkasyi. Based on this background, the problem that can be formulated is how the principle of K. H Imam Zarkasyi in educating the Darussalam Gontor Modern Islamic Boarding School students in Muhammad Ridlo Zarkasyi's book. The purpose of this study was to find out how the principle of KH Imam Zarkasyi's life in educating the students of Pondok Modern Darussalam Gontor in Muhammad Ridlo Zarkasyi's book. This type of research is library research that uses literature review material and the primary source is the book: Ajaran Kiai Gontor by Muhammad Ridlo Zarkasyi and the secondary source is taking from books, journals, articles related to research. The data analysis technique is using descriptive analysis and content analysis. The results of this study indicate that the secret of success according to KH Imam Zarkasyi in the book Ajaran Kiai Gontor by Muhammad Ridlo Zarkasyi is to get used to self-control, self-regulation and time management. Being a Muslim must be good at self-control, in the sense of jihad in all things, including fighting lust and not being wasteful in everything. Wasting time is also a waste of time. We must be able to take advantage of the time we have for a glorious future. KH Imam Zarkasyi also said "Don't get carried away with today's success". Because complacency is a disease for people who want success. From the journey of KH Imam Zarkasyi to his success, we can take the existing lessons and use them as lessons to welcome our future to achieve success as well.
\end{abstract}

Keywords: KH Imam Zarkasyi, Pondok Modern Darussalam Gontor, Success 


\section{INTRODUCTION}

Islamic boarding schools have a function as an educational and da'wah institution. Islamic boarding schools have grown and developed with their community members since centuries. Therefore, it is not only culturally acceptable, but has even participated in shaping and providing the movement and values of life in a society that is constantly growing and developing, the figures of kyai and santri as well as adequate physical equipment, a pesantren is always surrounded by a culture that is religious in nature. . The culture regulates the relationship between one society and another.

Islamic education at Pondok Modern Darussalam Gontor designed by KH. Imam Zarkasyi has a pesantren style. Education according to KH. Imam Zarkasyi is "everything that can affect goodness to the human spirit", be it from childhood to adulthood, to even being a parent. Therefore, according to him, humans always receive upbringing, as long as they have a spirit of holiness (humanity), or a healthy mind. Islamic education really wants to educate people towards a high and just social life. Education in Gontor is self-reliance. Its substance educates a person to become a more independent person. This was done none other than for da'wah and for Islam, because the main education of the pesantren founded by KH. Imam Zarkasyi is educating to be an independent leader, who is social, and as the glue of the people. Independent is emphasized so that students do not aspire to become employees. Santri can be employees, but good employees. In addition to educating students to be independent, education there is instilled with discipline. Education is also comprehensive not only in school but also in our daily life. How can a student attend a good school and become a good society. How about when a santri is appointed to lead, then he must be ready to lead and when not appointed then he must be ready to lead?

prepare that he will be led. "Ready to lead and ready to be led. Ready to educate and ready to be educated". And the most important thing in Gontor is training mentally. So students or students are trained mentally, mentally trained. Mental education will be realized if in educating students are invited to see the rich country with open eyes and mental skills so that it will be clear what areas of business they can do.

The purpose of this study was to find out how the life principle of KH Imam Zarkasyi in educating the students of Pondok Modern Darussalam Gontor according to Muhammad Ridlo Zarkasyi's book.

\section{THEORETICAL FRAMEWORK}

\section{Definition of Success}

Most success is linked to financial success. This means that someone is said to be successful if he manages to accumulate wealth or wealth from the results of his hard work. Success is interpreted as an advantage that must exist in the centers of power, both national and international levels, both human and product. Terms related to social success, such as the term leader, are always identified with leaders in the sense of power. The measure of educational success is no longer seen from the success of individuals who travel to nowhere, but is also measured by how successful education is in producing humans who are able to provide direct benefits to those around them.

\section{Definition of Santri}

Santri in general is a designation for someone who follows education religion Islam in boarding school, usually stay in that place until his education is complete. According to language, the term santri comes from thesanskrit,"shastri" which has the same root as the word literature which means scripture, religion and knowledge. (FerryEfendi,2019:331) Nur Cholish Madjid also has a different opinion. In his view, the origin of the word "Santri" 
can be seen from two opinions. First, the opinion that "Santri" comes from the word "sastri", a word from Sanskrit which means literate. This opinion, according to Nur Cholish Madjid, is based on the students of literary class for Javanese who try to explore religion through books written and in Arabic. Second, the opinion that says that the words of santri actually come from the Javanese language, from the word "cantrik" means someone who always follows a teacher where this teacher goes to live. (Yasmadi, 2005:61)

\section{Pondok Modern Darussalam Gontor}

Gontor was the first to introduce the term modern Islamic boarding school. Gontor himself defines modernity with connotations of good and positive values, such as discipline, neatness, hard work and militancy. However, not all Islamic boarding schools in Indonesia follow and imitate Pondok Modern Darussalam Gontor, both in terms of systems, academics, and institutions. With the renewal of the term and accompanied by reform of the current system, pesantren have begun to highlight their identity so that they can attract urban communities to send their sons/daughter to pesantren. Living with a schedule that is so tight and there are also many strict rules that adorn the days at the pesantren. The tight schedule and strict regulations are not an obstacle for Darussalam Gontor Islamic Boarding School students, but these two things are used as gemblengan and stepping stones so that they become orderly and regular habits to get to the twists and turns of success in the future. In pesantren, independence is taught. Must be able to manage time and solve various problems they face. Discipline and patience are the main keys. With such a terrible environmental habit, should later when it has descended among the community, it should be able to adjust and blend in with the community. Dedication to the community, of course, by giving what has been obtained from the results of planting knowledge in Islamic boarding schools

\section{RESEARCH METHODS}

This study uses a qualitative descriptive approach, and the type of research used is the library research method, namely collecting data or scientific papers related to the object of research or data collection. which is bibliographic. Qualitative research is research that is used to investigate, discover, describe, and explain the quality or features of social influence that cannot be explained, measured, or described through a quantitative approach.

\section{RESEARCH RESULTS AND DISCUSSION}

\section{a. Pondok Modern Darussalam Gontor}

Pondok Modern Darussalam Gontor was officially established on September 20, 1926, which coincided with 12 Rabiul Awwal 1345, right in commemoration of the Prophet's Birthday. Pondok Modern Darussalam Gontor was founded by three brothers, namely KH. Ahmad Sahal, KH. Zainuddin Fananie and KH. Imam Zarkasyi, who later became known as Trimurti. Pondok Modern Darussalam Gontor is an educational institution to produce intellectual teachers and scholars. Pondok Modern Darussalam Gontor is one of the Islamic boarding schools located in Ponorogo Regency, East Java. This Islamic boarding school is famous for its 
strict discipline, mastery of foreign languages, namely Arabic and English, as well as regeneration and a very strong alumni network.

The activity of the students started at $03.30 \mathrm{WIB}$, they were woken up by the hostel administrator to read the Qur'an and rushed to take preparations to establish the dawn prayer in congregation. After the Fajr prayer in congregation, the students continued their activities again. Learning activities are carried out in the morning, afternoon and evening. The busyness of activities makes the students accustomed to being busy with activities.

Everything is done independently, starting from taking care of the dormitory members, washing clothes, washing dishes to when they are sick they work together with each other. Which became a big and valuable lesson at Pondok Modern Darussalam Gontor is a lot of lessons about life that we can absorb and understand to be applied in the future when we are involved in society. Learning to organize from small to large has been directly applied in Gontor. From learning to organize called OPPM, Pondok Modern Student Organization. From being organized, there will be a sense of responsibility, leadership and community.

The Modern Pondok Student Organization (OPPM) is a forum for fostering and accommodating students' creativity in organizational training. The Modern Pondok Student Organization (OPPM), which was founded on July 6, 1967 , is intended as a means for students to be ready to lead and want to be led, including in the community in the future. The existence of the Modern Pondok Student Organization (OPPM) is inseparable from the daily life of students. Because the Modern Islamic Boarding School Student Organization (OPPM) manages and mobilizes all student activities, so that students can learn to take care of themselves.

It has been a century since Pondok Modern Darussalam Gontor has arrived in this country and thank God it has contributed everywhere, including in the intellectual realm. Starting from professors at universities, activists, to teachers in various parts of the country, there are Gontor alumni. All strive spiritually and intellectually to spread the da'wah of Islam. (Yanuardi:2021)

\section{b. The Life Principles of KH Imam Zarkasyi in Educating Santri Pondok Modern Darussalam Gontor in Muhammad Ridlo Zarkasyi's Book.}

The book "Teachings of Kiai Gontor" is a book that contains the principles of life and some advice from KH Imam Zarkasyi. In addition, this book also contains the values of life that are in accordance with the current situation. KH Imam Zarksyi's life is not as smooth as we imagine. Even though he has hundreds or even thousands of students, KH Imam Zarkasyi has also experienced a phase where he and his family endured hunger. However, it is not the figure of KH Imam Zarkasyi who just silently contemplates his life, he then moves to build business units. This business unit is also poured into the lives of students at Pondok Modern Darussalam Gontor.

There are student cooperatives, kitchen cooperatives, and various business units managed by the students of Pondok Modern Darussalam Gontor. They must report their performance in front of thousands of students every year. In this case, KH Imam Zarkasyi stated that this was an effort to educate the value of independence of his students. According to KH Imam Zarkasyi, someone who is successful is those who devote themselves to always being istiqomah in teaching. "For me, an 
alumni who lives in a remote village and teaches the Koran in a small surau is a successful alumni," added KH Imam Zarkasyi.

Success has a simple but profound meaning. So success means a success or luck. In the English dictionary, success means success and good results. So success is someone's success in achieving something. (Ifdal, 2005:5)Success is an achievement of a desire that we intend to achieve or the ability to go through and overcome from one failure to the next without losing enthusiasm. Success is closely related to our accuracy in determining goals, while goals are targets that we have set. (Marsudi,2016:62)

\section{Respect Yourself and Time}

The key to mental development is a strong will, discipline, and strong faith. The kiai have set an example for us on how they fight for the continuity of cottage education to be successful and move forward with "Bondo, shoulder, mind, lek, you need a lot of life" (Wealth, energy, mind, if necessary, with his life at once). (Rafiqi:2021)

Self-regulation or self-management, is a person's ability to recognize and manage himself physically, emotionally, mind, soul, and spiritually, so that he is able to manage other people and various resources. power to control and create the reality of life in accordance with the mission and purpose of life. (Ariwibowo: 2001) Self-management is the process of changing the totality of oneself. Self-regulation is very important for now and in the future.

Time management is the process of consciously planning and controlling the time spent on certain activities, especially to increase effectiveness, efficiency, and productivity.

\section{Stay away from being discouraged}

In this life we will always be faced with trials, tests, and problems. But do not shy away and run from the problem. We should solve problems, tests and trials calmly. Then make self-evaluation material so that it doesn't happen again in the future.

\section{Don't be afraid to make mistakes in learning}

The key to learning is process and change. We should learn so that we know, and for those who already know, then they will know more. Even then, of course, does not run directly, but there is a process. During the learning process there must be mistakes, failures, shortcomings and so on. This can't be avoided, because we don't know and we can't. So it's only natural that if you step in the beginning, most of you will experience that error. So if we continue to experience a structured learning process, then we will have a lot of knowledge that comes from various experiences, from there we will move to progress. Because this structured experience is different from knowledge obtained from books or from individual sources

\section{Keeping Trust As Best As Possible}

Rank is not an income. Rank is an additional workload and an additional mandate. If we only imagine increase in income by pursuing a promotion, then we will forget the 
burden of the mandate that we must carry with that rank.

\section{CONCLUSION}

The conclusion of the answer to the main problems in this study is that the life principle of KH Imam Zarkasyi adheres to his self-confidence, can control himself, manages time, is not afraid to make mistakes in learning, and maintains the trust and trust of others. In this way, KH Imam Zarkasyi can mature in life and provide many benefits for others.

\section{REFRENCES}

Alfian, Y. (2012, July 18). Success Measure. Retrieved from Stories Gontor: https://cepatgontor.wordpress.com/2012/07/18/ukur-hasil/

Efendi, F., \& Makhfudli. (2009). Community Health Nursing. Jakarta: Salemba Medika.

Marsudi. (2016). Life is a struggle. Jakarta: PT Persada.

Tantawi, R. (2019, October 25). Doing self-control and its relation to the development of our authority as human beings. Retrieved from BKM AtTaqwaUMA: https://bkmattaqwa.uma.ac.id/2019/10/25/melaksana- selfcontrol-and-its-relation-to-our-authority-building-as-humans/

Yasmadi. (2005). Islamic Boarding School Modernization. Jakarta: Ciputat Press. 